\title{
ENGLISH BOOK-ILLUSTRATION OF TO-DAY.
}

I. Some Decorative Illustrators.

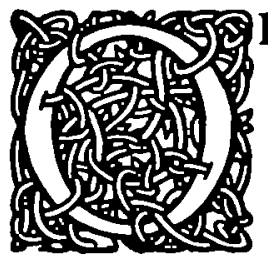

$F$ the famous ' Poems by Alfred Tennyson,' published in 1857 by Edward Moxon, Mr. Gleeson White wrote in 1897: "The whole modern school of decorative illustrators regard it rightly enough as the genesis of the modern movement.' The statement may need some modification to touch exact truth, for the 'modern movement' is no single file, straightforward movement. 'Kelmscott,' 'Japan,' the 'Yellow Book,' black-and-white art in Germany, in France, in Spain, in America, the influence of Blake, the style of artists such as Walter Crane, have affected the form of decorative book-illustration in the nineties. Such perfect unanimity of opinion as is here ascribed to a large and rather indefinitely related body of men hardly exists, among even the smallest and most derided body of artists. Still, allowing for the impossibility of telling the whole truth about any modern and eclectic form of art in one sentence, there is here a statement of fact. What Rossetti and Millais and Holman Hunt achieved in the drawings to the illustrated 'Tennyson' was a vital change in the direction of English illustra- 


\section{ENGLISH BOOK-ILLUSTRATION. 55}

tion, and whatever form decorative illustration may assume, their ideal is effective while a personal interpretation of the spirit of the text is the creative impulse in illustrative art. The influence of technical mastery is strong and enduring enough. It is constantly in sight and constantly in mind. But it is in discovering and making evident a principle in art that the influence of spirit on spirit becomes one of the illimitable powers.

To Rossetti the illustration of literature meant giving beautiful form to the aspect of delight, of penetration, that had kindled his imagination as he read. He illustrated the 'Palace of Art' in the spirit that stirred him to rhythmic expression in words of the still music in Giorgione's 'Pastoral,' or of the unpassing movement of Mantegna's 'Parnassus.' Not the words of the text, nor those things precisely affirmed by the writer, but the meaning, the spell of beauty that held his mind to the exclusion of other images, gave him inspiration for his drawings. As Mr. William Michael Rossetti says: 'He drew just what he chose, taking from his author's text nothing more than a hint and an opportunity.' It is said, indeed, that Tennyson could never see what the St. Cecily drawing had to do with his pqem. And that is strange enough to be true.

It is clear that such an ideal of illustration is for the attainment of a few only. The ordinary illustrator, making drawings for cheap reproduction in the ordinary book, can no more work in this mood than the journalist can model his style on the prose of Milton. But journalism is not literature, and 


\section{ENGLISH BOOK-ILLUSTRATION.}

pictured matter-of-fact is not illustration, though it is convenient and obligatory to call it so. However, here one need not consider this, for the decorative illustrator has usually literature to illustrate, and a commission to be beautiful and imaginative in his work. He has the opportunity of Rossetti, the opportunity for significant art.

The 'Classics' and children's books divide the art of decorative illustrators. Those who have illustrated children's books chiefly, or whose best work has been for the playful classics of literature, it is convenient to consider in a separate article, though there are instances where the division is not maintainable. Walter Crane, for example, whose influence on a school of decorative design makes his position at the head of his following imperative.

Representing the 'architectural' sense in the decoration of books, many years before the supreme achievements of William Morris added that ideal to generally recognized motives of book-decoration, Walter Crane is the precursor of a large and prolific school of decorative illustrators. Many factors, as he himself tells, have gone to the shaping of his art. Born in 1846 at Liverpool, he came to London in 1857 , and there after two years was 'apprenticed 'to Mr. W. J. Linton, the famous woodengraver. His work began with 'the sixties,' in contact with the enthusiasm and inspiration those years brought into English art. The illustrated 'Tennyson,' and Ruskin's 'Elements of Drawing,' were in his thoughts before he entered Mr. Linton's workshop, and the 'Once a Week' school had 

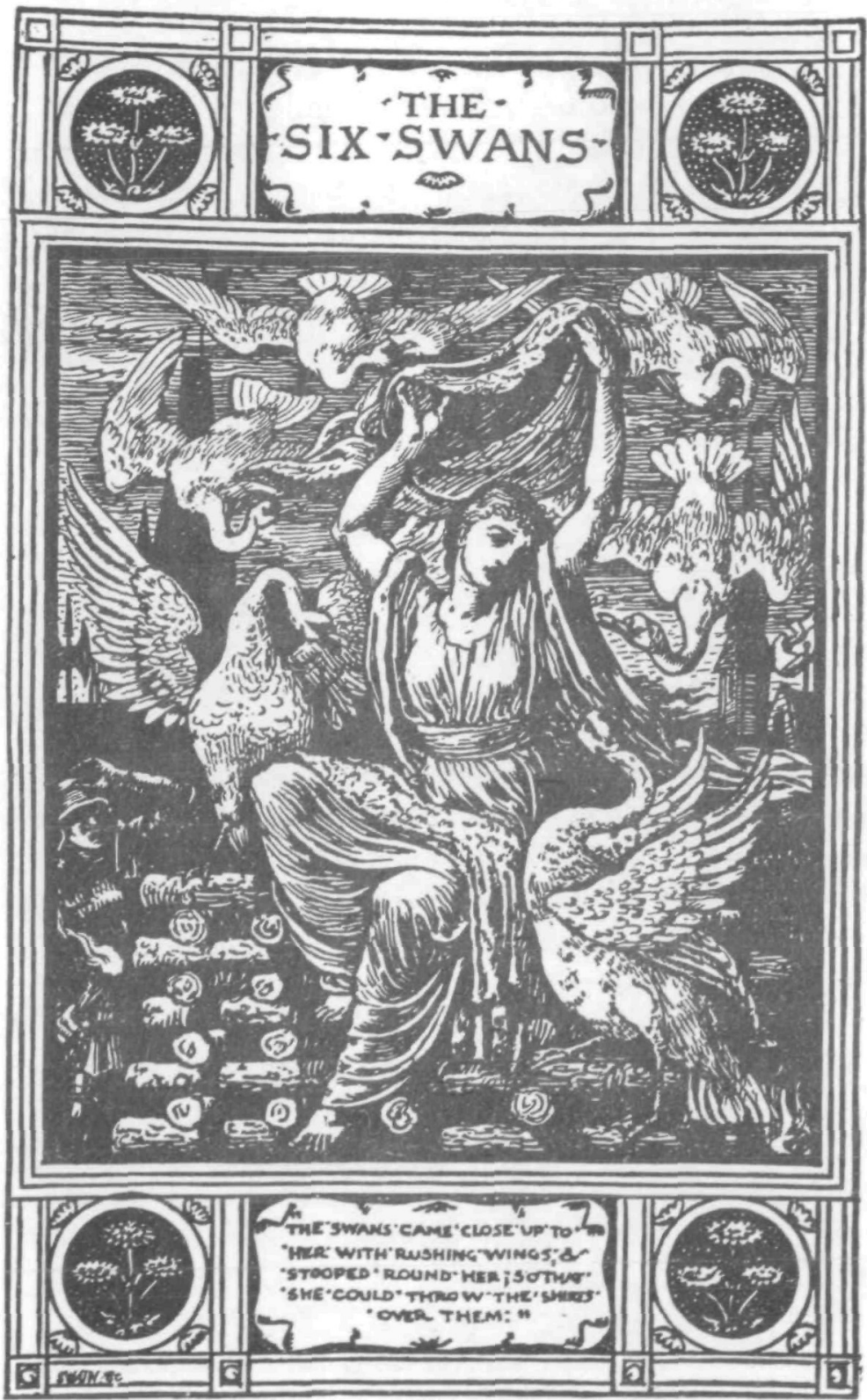

FROM MR. WALTER CRANE'S 'GRIMM'S HOUSEHOLD STORIES.' BY LEAVE OF MESSRS, MACMILLAN. 


\section{$5^{8}$ ENGLISH BOOK-ILLUSTRATION}

a strong influence on his early contributions to ' Good Words,' ' Once a Week,' and other famous numbers. In 1865 Messrs. Warne published the first toy-book, and by $1869-70$ the 'Walter Crane Toy-book' was a fact in art. The sight of some Japanese colour-prints during these years suggested a finer decorative quality to be obtained with tint and outline, and in the use of black, as well as in a more delicate simplicity of colour, the later toybooks show the first influence of Japanese art on the decorative art of England. Italian art in England and Italy, the prints of Dürer, the Parthenon sculptures, these were influences that affected him strongly. 'The Baby's Opera' (1877), and 'The Baby's Bouquet' ( 1879 ), are classics almost impossible to criticise, classics familiar from cover to cover before one was aware of any art but the art on their pages. So that if they seem less expressive of the supreme art of Greece, of Germany, of Italy, than of the countries by whose coasts ships 'from over the sea' go sailing by with strange cargoes and strange crews, of that land whence come broom-sellers and cradle-songs, it is not in their dispraise. As a decorative artist Mr. Crane is at his best when the use of colour gives clearness to the composition, but some of his most 'serious' work is in the black-an'd-white pages of "The Sirens Three,' 'Echoes of Hellas,' 'The Shepheardes Calendar,' and especially 'The Faerie Queene.' The number of books he has illustrated -upwards of seventy-makes a detailed account impossible. Nursery rhyme and fairy books, children's stories, the myths of Greece, Spenser, Shake- 


\section{OF TO-DAY.}

speare, 'pageant books' such as 'Flora's Feast' or 'Queen Summer,' or the just published 'Masque of Days,' his own writings, serious or gay, have given him subjects, as the great art of all times has touched the ideals of his art.

But whatever the subject, how strong soever his artistic admirations, he is always Walter Crane, unmistakable at a glance. Knights and ladies, fairies and fairy people, allegorical figures, nursery and school-room children, fulfil his decorative purpose without swerving, though not always without injury to their comfort and freedom and the life in their limbs. An individual apprehension that sees every situation as a decorative 'arrangement' is occasionally beside the purpose in rendering real life. But when his theme touches imagination, and is not a supreme expression of it-for then, as in the illustrations to 'The Faerie Queene,' an unusual sense of subservience appears to dull his spirit-his fancy knows no weariness nor sameness of device.

The work of most of Mr. Crane's followers belongs to 'the nineties,' when the 'Arts and Crafts' movement, the 'Century Guild' the Birmingham and other schools had attracted or produced artists working according to the canons of Kelmscott. Mr. Heywood Sumner was earlier in the field. The drawings to 'Sintram' ( 1883 ) and to 'Undine' (1888) show his art as an illustrator. Undinespirit of wind and water, flower-like in gladnessseeking to win an immortal soul by submission to the forms of life, is realized in the gracefully designed figures of frontispiece and title-page. Where 


\section{ENGLISH BOOK-ILLUSTRATION}

Mr. Sumner illustrates incident he is 'factual' without being matter-of-fact. The small drawing reproduced is hardly representative of his art, but most of his work is adapted to a squarer page than

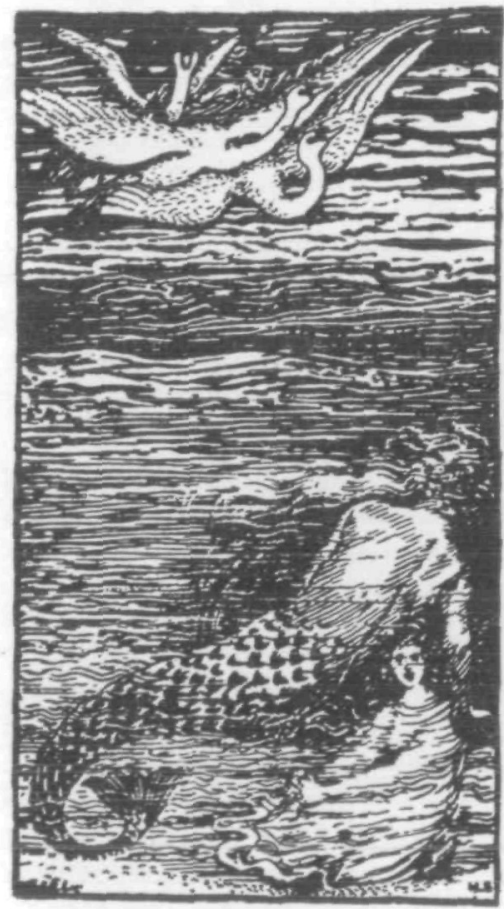

FROM MR. HEYWOOD SUMNER'S 'UNDINE.'

BY LEAVE OF MESSRS. CHAPMAM AND HALL. that of 'The Library,' and has had to be rejected on that account. Some of the 'most apt decorations in "The English Illustrated' were by Mr. Sumner, and during the time when art was represented in the magazine Mr. Ryland and Mr. Louis Davis were frequent contributors. The graceful figures of Mr. Ryland, uninterested in activity, a garden-world set with statues around them, and the carol-like grace of Mr. Davis's designs in that magazine, represent them better than the one or two books they have illustrated.

Among those associated with the 'Arts and Crafts' who have given more of their art to book-decoration than these men, Mr. Anning Bell is first. $\mathrm{He}$ has gained the approval even of the most exigent of critics as an artist who understands drawing for 
process. Since 1895, when the 'Midsummer Night's Dream' appeared, his winning art has been praised with discrimination and without discrimination, but always praised. Trained in an architect's office, widely known as the re-creator of coloured relief for architectural decoration, $\mathrm{Mr}$. Anning Bell's illustrative art shows constructive power no less than that fairy gift of seeming to improvise without labour and without hesitancy, which is one of its especial charms. In feeling, and in many of his decorative forms, he recalls the art of Florentine bas-relief, when Agostino di Duccio, or Rossellino or Mino da Fiesole, created forms of delicate sweetness, pure, graceful - so graceful that their power is hardly realized. The fairy by-play of the 'Midsummer Night's Dream' is exactly to Mr. Anning Bell's fancy. He knows better than to go about to expound this dream, and it is not likely that a more delightful edition will ever be put into the hands of children, or of anyone, than this in the white and gold cover devised by the artist.

Of his illustrations to the 'Poems by John Keats' (1897), and to the 'English Lyrics from Spenser to Milton' of the following year-as illustrations-not quite so much can be said, distinguished and felicitous as many of them are. The simple profile, the demure type of beauty that he affects, hardly suits with Isabella when she hears that Lorenzo has gone from her, with Lamia by the clear pool

"Wherein she passionëd

To see herself escaped from so sore ills," 


\section{ENGLISH BOOK-ILLUSTRATION}

or with Madeline, 'St. Agnes' charmëd maid.' Mr. Anning Bell's drawings to 'The Pilgrim's Progress' $(\mathrm{r} 898)$ reveal him in a different mood, as do those in 'The Christian Year' of three years earlier. His vision is hardly energetic enough, his energy of belief sufficient, to make him a strong illustrator of Bunyan, with his many moods, his great mood. A little these designs suggest Howard

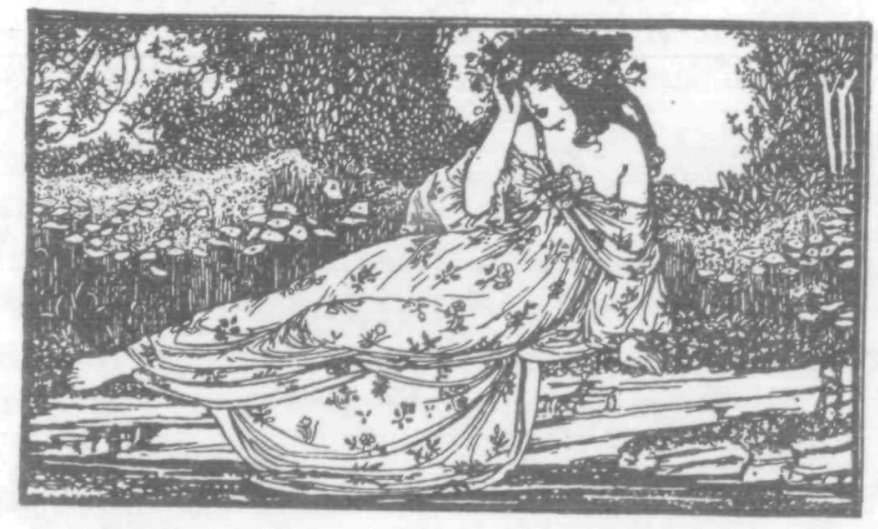

TROM MR. ANNING BELL'S 'KBATS.'

BY LEAVE OF MESSRS. GEORGE BELL.

Pyle, and Anning Bell is better in a way of beauty not Gothic.

So if Mr. Anning Bell represents the 'Arts and Crafts' movement in the variety of decorative arts he has practised, and in the architectural sense underlying all his art, his work does not agree with the form in which the influence of William Morris on dizcorative illustration has chiefly shown itself. That form, of course, is Gothic, as the ideal of Kelnuscott was Gothic. The work of the 
' Century Guild ' artists as decorative illustrators is chiefly in the pages of 'The Hobby Horse.' I do not think either Mr. Selwyn Image or Mr. Herbert Horne has illustrated books, so in this connection one may not stop to consider the decorative strength of their ideal in art. The Birmingham school represents Gothic ideals with determination and rigidity. Morris addressed the students of the school and prefaced the edition of 'Good King Wenceslas,' decorated and engraved and printed by Mr. A. J. Gaskin 'at the press of the Guild of Handicraft in the City of Birmingham,' with cordial words of appreciation for the pictures. These illustrations are among the best Mr. Gaskin has done. The twelve full-page drawings to 'The Shepheardes Calendar,' printed at the Kelmscott Press in 1896 , mark Morris's pleasure in Mr. Gaskin's workthis time seen in Andersen's 'Stories and Fairy Tales.' If not quite in tune with Spenser's Elizabethan idyllism, these drawings are distinctive of the definite convictions of the artist.

These convictions represent a splendid tradition. They are expressive, in their regard for the unity of the page, for harmony between type and decoration, of the universal truth in all fine bookmaking. Only at times Birmingham work seems rather heavy in spirit, rather too rigid for development. Still, judging by results, a code that would appear to be against individual expression is inspiring individual artists. Some of these-as Mr. E. H. New-have turned their attention to architectural and "open air" illustration, in which connection their work will be considered, and many 


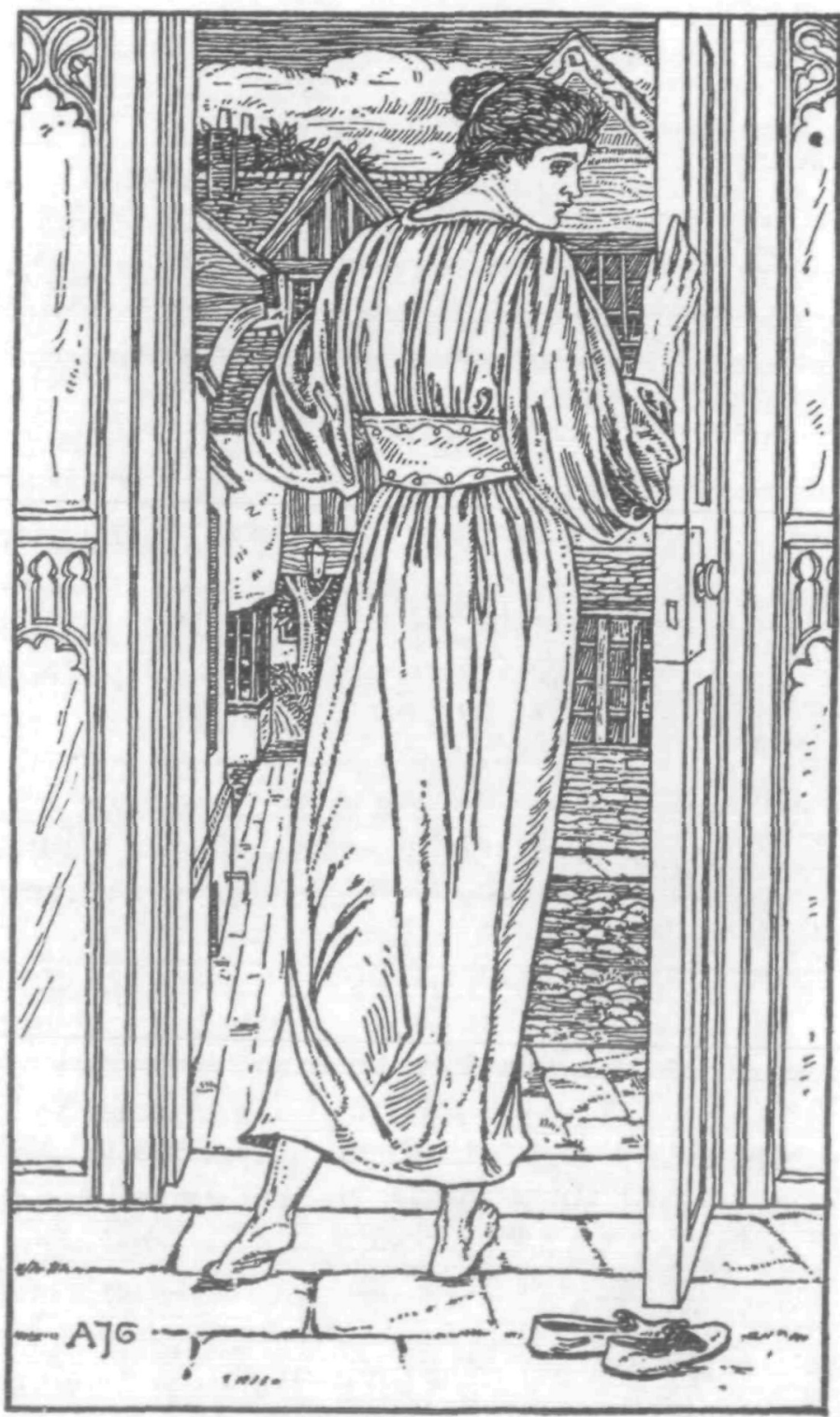

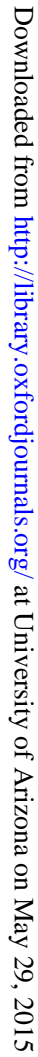

FROM YAR. GASKIN'S 'HANS ANDERSEN.' BY LEAVE OF MR, GLORGE ALLER, 


\section{ENGLISH BOOK-ILLUSTRATION. 65}

have illustrated children's books.' Their quaint and naive fancy has there, at times produced a portentous embodiment of the 'old-fashioned' child of fiction. Mr. Gere, though he has done little book-illustration, is one of the strongest artists of the school. His original wood engravings show unmistakably his decorative power and his craftsmanship. With Mr. K. Fairfax Muckley he was responsible for 'The Quest' (1894-96). Mr. Fairfax Muckley has illustrated and decorated a threevolume edition of 'The Faerie Queene' (1897), wherein the forest branches and winding ways of woodland and of plain are more happily conventionalized than are Spenser's figures. Some of the headpieces are especially successful. The artist uses the 'mixed convention' of solid black and line work with less confusion than many modern draughtsmen. Once its dangers must have been evident, but now the puzzle pattern, with solid blacks in the foreground, background, and middistance-only there is no distance in these drawings-is the most usual form of black and white.

Miss Celia Levetus, Mr. Henry Payne, Mr. F. Mason, and Mr. Bernard Sleigh, are also to the credit of the school. Miss Levetus, in her later work, shows that an inclination towards a more flexible style is not incompatible with the training in medixval convention. Mr. Mason's illustrations to ancient romances of chivalry give evidence of conscientious craftsmanship, and of a spirit sympathetic to themes such as 'Renaud of Montauban.' Mr. Bernard Sleigh's original wood-engravings are well known and justly appreciated. Strong in tras. III. 


\section{ENGLISH BOOK-ILLUSTRATION}

dition and logic as is the work of these designers, it is, for many, too consistent with convention to be delightful. Perhaps the best result of the Birmingham school will hardly be achieved until the formal effect of it is less patent..

The "sixties" might have been void of art, so far as these designers are concerned, save that in those days Morris and Burne-Jones and Walter Crane, as well as Millais and Houghton and Sandys, were about their work. Far other is the case with artists such as Mr. Byam Shaw, or with the many draughtsmen, including Messrs. P. V. Woodroffe, Henry Ospovat, Philip Connard, and Herbert Cole, whose art derives its form and intention from the sixties. Differing in technical power and fineness of invention, in all that distinguishes good from less good, they have this in common-that the form of their art would have been quite other if the illustrated books of the sixties were among things unseen. Mr. Byam Shaw began his work as an illustrator in 1897 with a volume of 'Browning's Poems,' edited by Dr. Garnett. He proved himself in these drawings, as in his pictures and later illustrations, an artist with a definite memory for the forms, and a genuine sympathy with the aims of pre-Raphaelite art. Evidently, too, he admires the black-andwhite of Mr. Abbey. He has the gift of dramatic conception, sees a situation at high pitch, and has a pleasant way of giving side-lights, pictorial asides, in the form of decorative head and tailpieces. His illustrations to the little green and gold volumes of the 'Chiswick Shakespeare' are more emphatic than his earlier work, and in the decorations his 
power of summarizing the chief motive is put to good use. There is no need of his signature to distinguish the work of Byam Shaw, though he shows himself under the influence of various masters. Probably he is only an illustrator of books by the way, but in the meantime, as the 'Boccaccio,' 'Browning,' and 'Shakespeare' drawings show, he works in black and white with vigorous intention.

Mr. Ospovat's illustrations to 'Shakespeare's Sonnets' and to 'Matthew Arnold's Poems' are interesting, if not very markedly his own. He illustrates the Sonnets as a celebration of a poet's passion for his mistress. In the Matthew Arnold drawings, as in these, he shows some genuine creative power and an aptitude for illustrative decoration. Mr. Philip Connard has made spirited and well-realized illustrations in somewhat the same kind; Miss Amelia Bauerle, and Mr. Bulcock, who began by illustrating 'The Blessed Damozel' in memory of Rossetti, have made appearance in the 'Flowers of Parnassus' series, and Mr. Herbert Cole, with three of these little green volumes, prepared one for more important work in 'Gulliver's Travels' ( 1900$)$.

The work of Mr. Woodroffe was, I think, first seen in the 'Quarto'-the organ of the Slade School-where also Mr. A. Garth Jones, Mr. Cyril Goldie, and Mr. Robert Spence, gave unmistakable evidence of individuality. Mr. Woodroffe's woodengravings in the 'Quarto' showed strength, which is apparent, too, in the delicately characterized figures to 'Songs from Shakespeare's Plays' (1898), with their borders of lightly-strung field flowers. 
His drawings to 'The Confessions of S. Augustine,' engraved by Miss Clemence Housman, are in keeping with the text, not impertinent. Mr. A. Garth Jones in the 'Quarto' seemed much influenced by Japanese grotesques; but in illustrations to Milton's 'Minor Poems' (1898) he has shown development towards the expression of beauty more austere, classical, controlled to the presentment of Milton's high thought. His recent 'Essays of Elia' remind one of the forcible work of Mr. E. J. Sullivan in 'Sartor Resartus.' Mr. Sullivan's 'Sartor' and 'Dream of Fair Women' must be mentioned. His mastery over an assertive use of line and solid black, the unity of his effects, the humour and imagination of his decorative designs, are not likely to be forgotten, though the balance of his work in books such as 'White's Selborne' or 'The Compleat Angler,' obliges one to class him with 'OpenAir' illustrators, and so to leave a blank in this article.

Mr. Laurence Housman stands alone among modern illustrators, though one may, if one will, speak of him as representing the succession of the sixties, or as connected with the group of artists whose noteworthy development dates from the publication of 'The Dial' by Charles Ricketts and Charles Shannon in 1889 . To look at Mr. Housman's art in either connection, or to record the effect of Dürer, of Blake, of Edward Calvert, on his technique, is only to come back to appreciation of all that is his own. As an illustrator he has hardly surpassed the spirit of the "forty-four designs, drawn and written by Laurence Housman,' 
that express his idea of George Meredith's 'Jump to Glory Jane' (1890). These designs were the result of the appreciation which the editor, Mr. Harry Quilter, felt for Mr. Housman's drawings to 'The Green Gaffer' in 'The Universal Review.' Jane — the village woman with 'wistful eyes in a touching but bony face,' leaping with countenance composed, arms and feet 'like those who hang,' leaping in crude expression of the unity of soul and body, making her converts, failing to move the bishop, dying at last, though not ingloriously, by the wayside - this most difficult conception has no 'burlesque outline' in Mr. Housman's work, inexperienced and unacademic as is the drawing.

'Weird Tales from Northern Seas,' by Jonas Lie, was the next book illustrated by Mr. Housman. Christina Rossetti's 'Goblin Market' (1893), offered greater scope for freakish imagination than did 'Jane.' The goblins, pale-eyed, mole and rat and weasel-faced; the sisters, whose simple life they surround with hideous fantasy, are realized in harmony with the unique effect of the poem-an effect of simplicity, of naive imagination, of power, of things stranger than are told in the cry of the goblin merchants, as at evening time they invade quiet places to traffic with their evil fruits for the souls of maidens. The frail-bodied elves of "The End of Elfin Town,' moving and sleeping among the white mushrooms and slender stalks of field flowers, are of another land than that of the goblin merchant-folk. Illustrations to 'The Imitation of Christ,' to 'The Sensitive Plant,' and drawings to 


\section{ENGLISH BOOK-ILLUSTRATION}

'The Were-Wolf,' by Miss Clemence Housman, complete the list of Mr. Housman's illustrations to writings not his own, with the exception of frontispiece drawings to several books.

To explain Mr. Housman's reading of 'The Sensitive Plant' would be as superfluous as it would be ineffectual. In a note on the illustrations he has told how the formal beauty, the exquisite ministrations, the sounds and fragrance and sweet winds of the garden enclosed, seem to him as 'a form of beauty that springs out of modes and fashions,' too graceful to endure. In his pictures he has realized the perfect ensemble of the garden, its sunny lawns and rose-trellises, its fountains, statues, and flower-sweet ways; the spirit of the Sensitive Plant, the lady of the garden, and Pan-Pan, the great god who never dies, who waits only without the garden, till in a little while he enters, ' effacing and replacing with his own image and superscription, the parenthetic grace . . . of the garden deity.' These drawings are very charming. Of a talent that treats always of enchanted places, where 'reality' is a long day's journey down a dusty road, it is difficult to speak without suggesting that it is all just a charming dalliance with pretty fancies, lacking strength. For the strength of Mr. Housman's imagination, however, his work speaks. His illustrations to his own writings, fairy tales, and poems, cannot with any force be discussed by themselves. The words , belong to the pictures, the pictures to the words. The drawings to 'The Field of Clover' are seen to full advantage in the wood-engravings of Miss Housman. Only 
so, or in reproduction by photogravure, is the full intention of Mr. Housman's pen-drawings apparent.

One may group the names of Charles Ricketts, C. H. Shannon, T. Sturge Moore, Lucien Pissarro, and Reginald Savage together in memory of 'The Dial,' where the activity of five original artists first became evident, though, save in the case of Mr. Ricketts and Mr. Shannon, no continuance of the classification is possible. The first number of 'The Dial,' 1889, had a cover design cut on wood by Mr. C. H. Shannon-afterwards replaced by the design of Mr. Ricketts. Twelve designs by Mr. Ricketts may be said to represent the transitional-or a transitional-phase of his art, from the earlier work in magazines, which he disregards, to the reticent expression of 'Vale Press' illustrations. In 189 I the first book decorated by these artists appeared, 'The House of Pomegranates,' by Oscar Wilde. There was, however, nothing in this book to suggest the form their joint talent was to take. Many delightful designs by Mr. Ricketts, somewhat marred by heaviness of line, and full-page illustrations by Mr. Shannon, printed in an almost invisible, nondescript colour, contained no suggestion of 'Daphnis and Chloe.'

The second 'Dial' (1892) contained Mr. Ricketts' first work as his own wood-engraver, and in the following year the result of eleven months' joint work by Mr. Ricketts and Mr. Shannon was shown in the publication of 'Daphnis and Chloe,' with thirty-seven woodcuts by the artists. Fifteen of the pictures were sketched by Mr. Shannon and revised and drawn on the wood by Mr. Ricketts, 


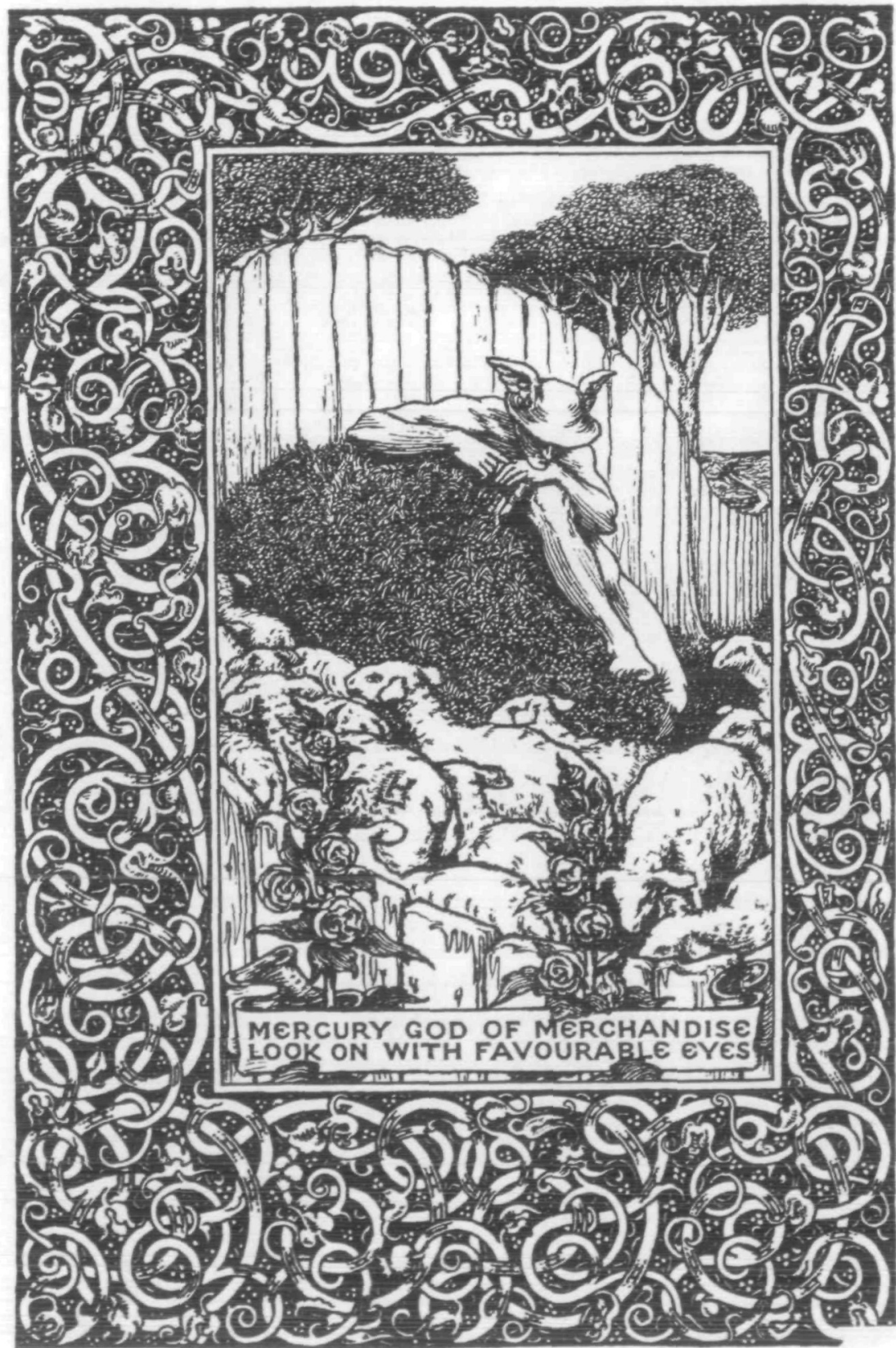

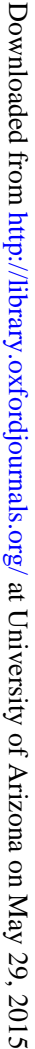

By LeATE OF MESsEs. KEgan PAUL 


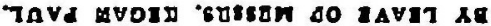

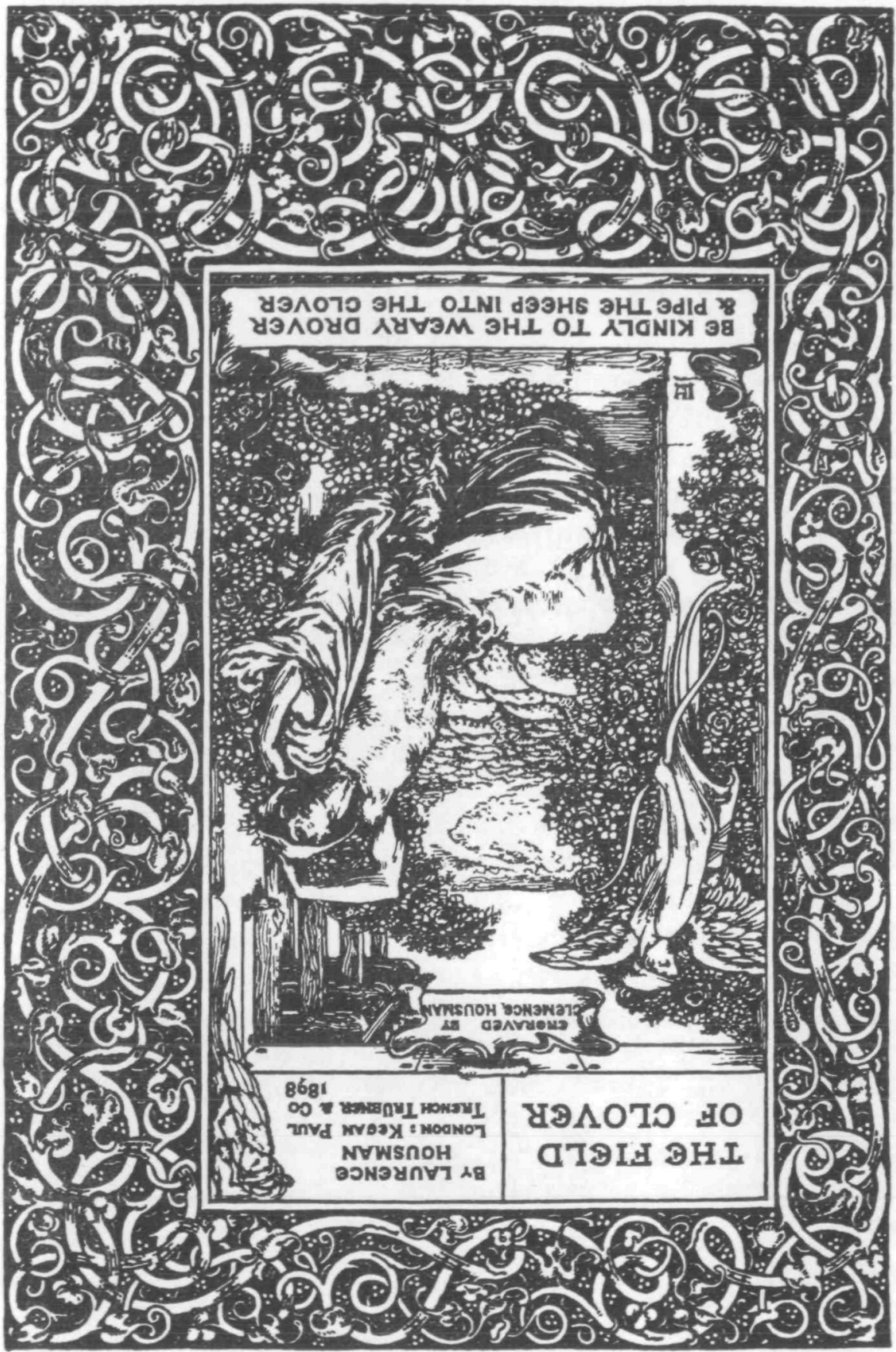

0
0
3
0
0
0
0
0
0
0
0
$\vdots$
0
0
0
0
0
0
0
0
0
0
0
0
0
0
0
0
0
0
0
0
0
0
0
0
0
0
0
0
0
0
0
0
0
0 


\section{ENGLISH BOOK-ILLUSTRATION.}

who also engraved the initials. It is a complete achievement of individuality subordinated to an ideal. Here and there one can affirm that $\mathrm{Mr}$. Shannon drew this figure, composed this scene, Mr. Ricketts that; but generally the hand is not to be known. The ideal of their inspiration-the immortal ' Hypnerotomachia'-seems equally theirs, equally potent over their individuality. Speaking with diffidence, it would seem as though Mr. Shannon's idea of the idyll were more naive and humorous. Incidents beside the main theme of the pastoral loves of young Daphnis and Chloethe household animals, other shepherds - are touched with humorous intent. Mr. Ricketts shows more suavity, and, as in the charming doublepage design of the marriage feast, a more lyrical realization of delight and shepherd joys.

The 'Hero and Leander' of 1894 is a less elaborate, and, on the whole, a finer production. I must speak of the illustrations only, lest consideration of Vale Press achievements should fill the remaining space at my disposal. Obviously the attenuated type of these figures shows Mr. Ricketts' ideal of the human form as a decoration for a page of type. The severe reticence he imposes on himself is in order to maintain the balance between illustrations and text. One has only to turn to illustrations to Lord de Tabley's 'Poems,' published in I 893, to see with what eager imagination he realizes a subject, how strong a gift he has for dramatic expression. That a more persuasive beauty of form was once his wont, much of his early and transitional work attests. But I do 
OF THE APPARITION OF THE THREE NYMPHS TO DAPHNE IN A DREAM.

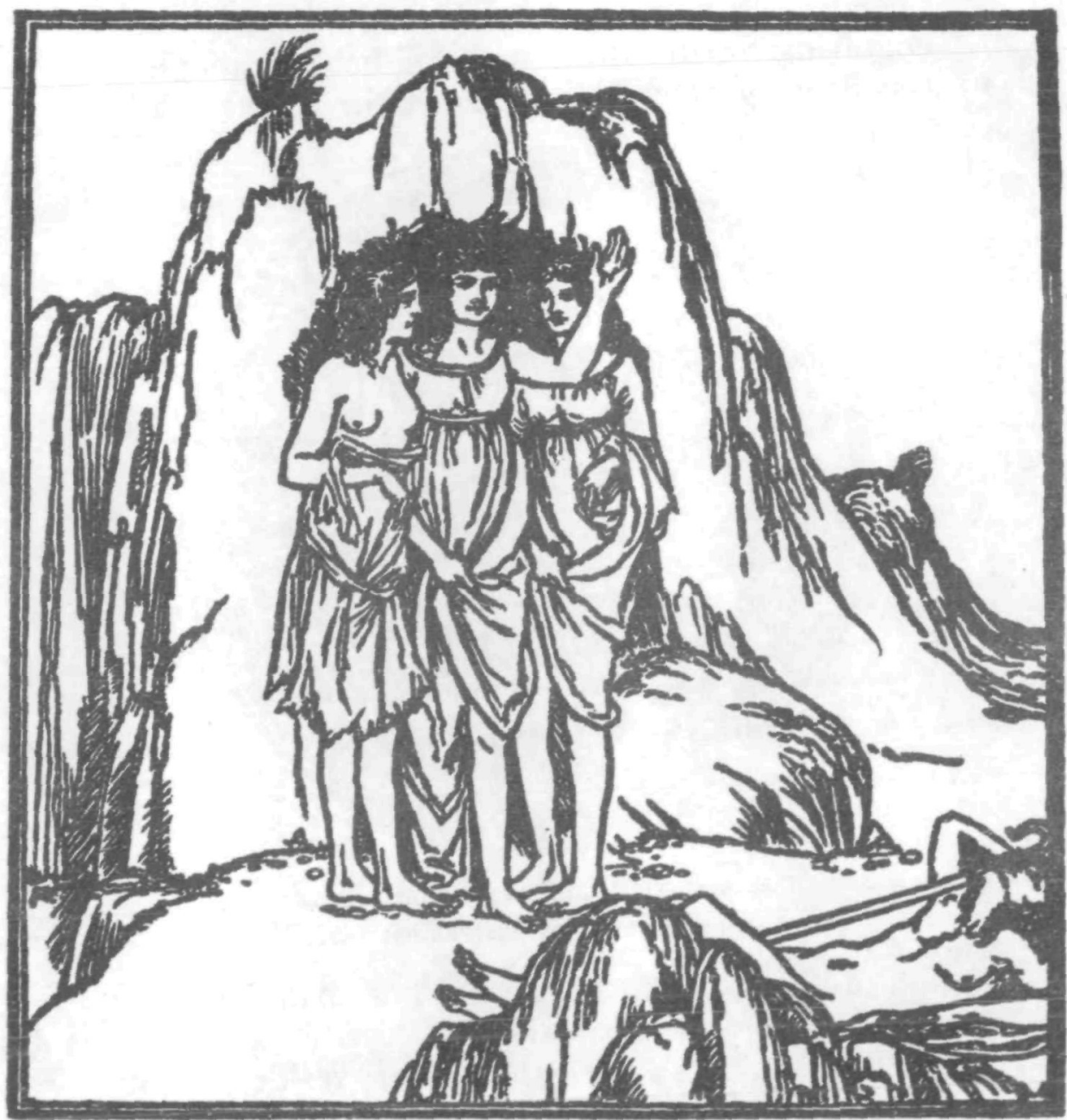

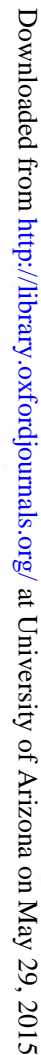

FROM MESSRS, RICKETTS AND SHANNON'S 'DAPHNIS AND CHLOR.'

(MATHEWS AND LANE.)

REPRODUCED BY THEIR LEAVE AND THE PUBLISHER'. 


\section{ENGLISH BOOK-ILLUSTRATION}

not think his power to achieve beauty need be defended. After the publication of "Hero and Leander,' Mr. Shannon practically ceased woodengraving for the illustration of books, though, as the series of roundel designs in the recent exhibi-

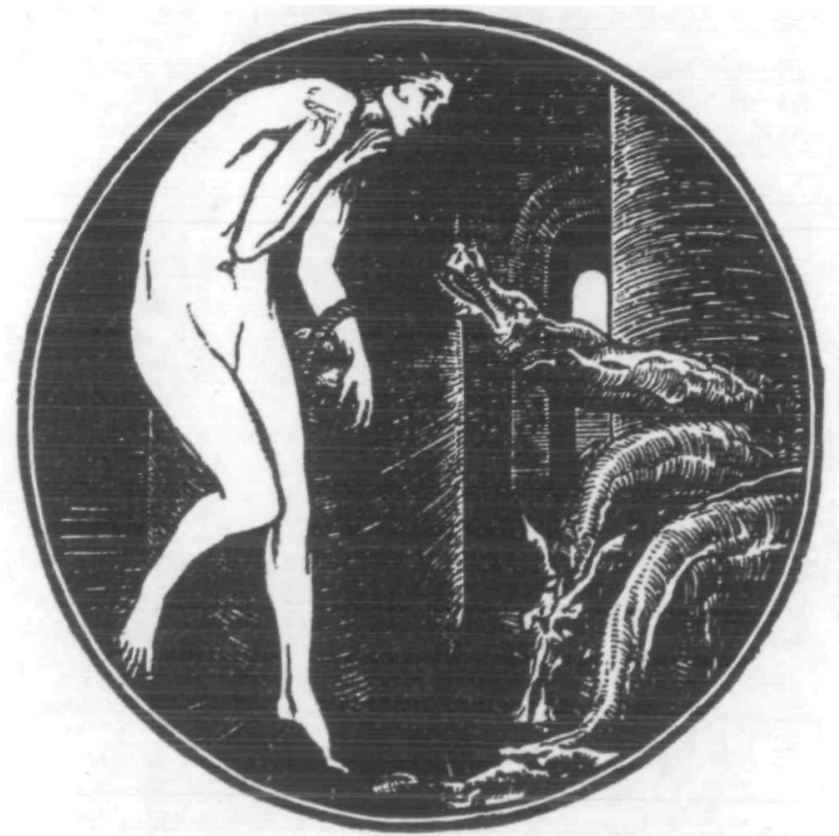

FROM MR. RICKETTS' ' CUPID AND PSYCHE.'

REPLODUCED BY HIS PBRMISEIOH.

tion of his work proved, he has not abandoned nor ceased to go forward in the art.

'The Sphinx,' a poem by Oscar Wilde, 'built, decorated and bound ' by Mr. Ricketts-but without woodcuts-was published in 1894 , just after ' Hero and Leander,' and designs for a magnificent edition of 'The King's Quhair' were begun. 
Some of these are in 'The Dial,' as also designs for William Adlington's translation of 'Cupide and Psyches' in ' The Pageant,' 'The Dial,' and 'The Magazine of Art.' The edition of the work published by the new Vale Press in 1897 , is not that projected at this time. It contains roundel designs in place of the square designs first intended. These roundels are, I think, the finest achievement of Mr. Ricketts as an original wood-engraver. The engraving reproduced shows of what quality are both line and form, how successful is the placing of the figure within the circle. On the page they are what the artist would have them be. With the beginning of the sequence of later Vale Press books-books printed from founts designed by $\mathrm{Mr}$. Ricketts-a consecutive account is impossible, but the frontispiece to the 'Milton' and the borders and initials designed by Mr. Ricketts, must be mentioned. As a designer of book-covers only one failure is set down to Mr. Ricketts, and that was ten years ago, in the cover to 'The House of Pomegranates.'

Mr. Reginald Savage's illustrations to some tales from Wagner by Mr. Farquharson Sharp lack the force of the 'Rhinoceros and Peacock' in 'The Pageant,' or of designs for 'The Ancient Mariner' and 'Sidonia the Sorceress.' Of $M$. Lucien Pissarro, in an article overcrowded with English illustrators, I cannot speak. His fame is in France as the forerunner of his art, and we in England know his coloured wood-engravings, his designs for 'The Book of Ruth and Esther' and for 'The Queen of the Fishes,' printed at his press at - Epping, but included among Vale Press books. 


\section{ENGLISH BOOK-ILLUSTRATION}

'The Centaur,' 'The Bacchant,' 'The Metamorphoses of Pan,' 'Siegfried'-young Siegfried, wood-nurtured, untamed, setting his lusty strength against the strength of the brutes, hearing the birdcall then, and following the white bird to issues remote from savage life-these are subjects realized by the imagination of Mr. T. Sturge Moore.

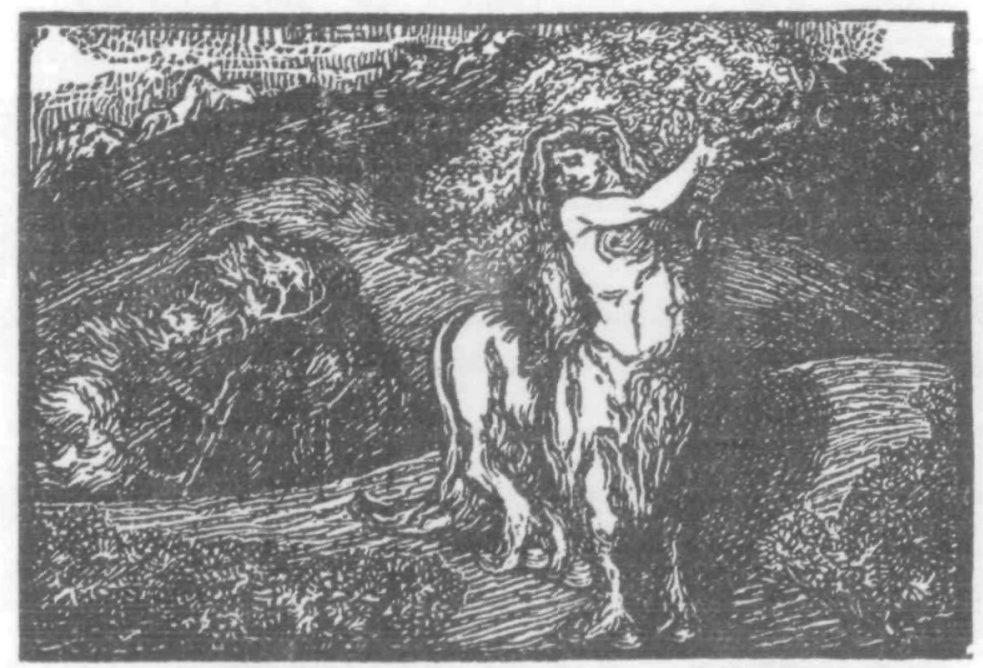

FROM MR. STURGE MOORE'S 'THE CENTAUR.' REPRODUCED BY PERMISSION OF MR. RICKETTS.

There is no artist illustrating books to-day whose work is more unified, imaginatively and technically. It is some years now since first Mr. Moore's woodengravings attracted notice in 'The Dial' and 'The Pageant,' and the latest work from his graver -finer, more rhythmic in composition though it be-shows no change in ideals, in the direction of his powers. He has said, I think, that the easiest 
line for the artist is the true basis of that artist's work, and it would seem as though much deliberation in finding that line for himself had preceded any of the work by which he is known. The wood-engraving of Mr. Sturge Moore is of considerable importance. Always the true understanding of his material, the unhesitating realization of his subject, combine to produce the effect of inevitable line and form, of an inevitable setting down of forms in expression of the thought within. Only that gives the idea of formality, and Mr. Moore's art handles the strong impulse of the wild creatures of earth, of the solitary creatures, mighty and terrible, haunting the desert places and fearing the order men make for safety. Designs to Wordsworth's 'Poems,' not yet published, represent with innate perception the earth-spirit as Wordsworth knew it, when the great mood of 'impassioned contemplation' came upon his careful spirit, when his heart leapt up, or when, wandering beneath the wind-driven clouds of March, at sight of daffodils, he lost his loneliness.

'The Evergreen,' that 'Northern Seasonal,' represented the pictorial outlook of an interesting group of artists-Robert Burns, Andrew K. Womrath, John Duncan, and James Cadenhead, for example-and the racial element, as well as their own individuality, distinguishes the work of $\mathrm{Mr}$. W. B. Macdougall and Mr. J. J. Guthrie of 'The Elf.' Mr. Macdougall has been known as a bookillustrator since 1896 , when 'The Book of Ruth, with decorated borders showing the fertility of his designing power, and illustrations that were no less 


\section{ENGLISH BOOK-ILLUSTRATION}

representative of a unique use of material, appeared. The conventionalized landscape backgrounds, the long, straightly-draped women, seemed strange enough as a reading of the Hebrew pastoral, with its close kinship to the natural life of the free children of earth. Their unimpassioned faces, unspontaneous gestures, the artificiality of the whole impression, were undoubtedly a new reading of the ancient charm of the story. Two books in 1897 , and 'Isabella' and 'The Shadow of Love,' I 898 , showed beyond doubt that the manner was not assumed, that it was the expression of Mr. Macdougall's sense of beauty. The decorations to 'Isabella' were more elaborate than to 'Ruth,' and inventive handling of natural forms was as marked. Again, the faces are decharacterized in accordance with the desire to make the whole figure the symbol of passion, and that without emphasis. Mr. J. J. Guthrie is hardly among book-illustrators, since 'Wedding Bells' of 1895 is not Mr. Guthrie, nor is the child's book of the following year, while the illustrations to Edgar Allan Poe's 'Poems' are still, I think, being issued from the Pear Tree Press in single numbers. His treatment of landscape is inventive, but his rhythmic arrangements, his effects of white line on black, are based on a real sense of the beauty of earth, of tall trees and wooded hills, of mysterious moon-brightness and shade in the leafy depths of the woodlands.

Mr. Granville Fell made his name known in 1896 by his illustrations to 'The Book of Job.' In careful detail, drawn with fidelity, never obtrusive, his art is pre-Raphaelite. He touches 
Japanese ideals in the rendering of flower-g: $\supset$ wth and animals, but the whole effect of his decorative illustrations is far enough away from the art of Japan. In the 'Job' drawings he had a subject sufficient to dwarf a very vital imaginative sense by its grandeur. In the opirion of competent critics Mr. Granville Fell proved more than the technical distinction of his work by the manner in which he fulfilled his purpose. The solid black and white, the definite line of these drawings, were laid aside for the sympathetic medium of pencil in 'The Song of Solomon' (1897). Again, his conception is invariably dramatic, and never crudely dramatic, robust, with no trace of morbid or sentimental thought about it. The garden, the wealth of vineyard and of royal pleasure ground, is used as a background to comely and gracious figures. His other work, illustrative of children's books and of legend, the cover and title-page to Mr. W. B. Yeats's 'Poems,' show the same strong yet restrained imagination.

Mr. Patten Wilson is somewhat akin to Mr. Granville Fell in the energy and soundness of his conceptions. Each of these artists is, as we know, a colourist, delighting in brilliant and iridescent colour-schemes, yet in black and white they do not seek to suggest colour. Mr. Patten Wilson's illustrations to Coleridge's 'Poems' have the careful fulness of drawings well thought out, and worked upon with the whole idea definite in the imagination. He has observed life carefully for the purposes of his art. But it is rather in rendering the . circumstance of poems, such as 'The Ancient III. 


\section{ENGLISH BOOK-ILLUSTRATION}

Mariner,' or, in his Chaucer illustrations-Constance on the lonely ship-that he shows his grasp of the subject, than by any expression of the spiritual terror or loneliness of the one living man among the dead, the solitary woman on strange seas.

Few decorative artists express themselves habitually in 'wash' rather than by line. Among those who rarely use the pen Mr. Weguelin and Mr. W. E. F. Britten must be named. Mr. Weguelin has illustrated Anacreon in a manner to earn the appreciation of Greek scholars, and his illustrations to Hans Andersen have had a wider and not less appreciative reception. His drawings have movement and atmosphere. Mr. Britten illustrated poems on the months by Mr. Swinburne in the 'Magazine of Art' in 1892-3, and since that time his version of ' Undine,' and illustrations to Tennyson's 'Early Poems,' have shown the same power of graceful composition and sympathy with his subject.

R. E. D. SKetchleY.

\section{BIBLIOGRAPHY.}

(To stramber, 1901.)

Amrita Badrzle.

Allogries. Frederic W. Fartar. 8\%. (Longmans, 1898.) 20 illust.

Tbe Day-Dream. Alfred Tennyson. 8\%. (Lane, 1901. (Flowers of Parnassus.')

R. Ansme Bell.

Tbe Golden Treassong of Att and Seng. Edited by R. E. Mack. $4^{\circ}$. (Nister, 189a.) 18 illust in colour. 
Fack the Giant-Riller and Beauty and the Beast. Edited by Grace Rhys. 32‥ (Dent, 1894 . Banbury Cross Series.) 35. The Slseping Beauty and Dick Whittington and bis Cat. Edited by Grace Rhys. 32․ (Dent, 1894 Banbury Cross Series.) 35.

The Cbristian Year. 8०. (Methuen, 1895.$) 5$.

1 Midsummer Nigbt's Driam. 40. (Dent, 1895.) 13, head and tailpieces, borders.

Keats' Pocms. Edited by Walter Raleigh. 8॰. (Bell, 1897 . Endymion Series.) 65.

English Lyrics from Sponser to Mitton. 8ొ. (Bell, 1898. Endymion Series.) 20, head and tailpieces.

Pilgrim's Progress. 80. (Methuen, 1898.) 39.

Lamb's Tales from Sbakespearc. 80. (Fremantle, 1899.) 15. Keats' Odes. 8०. (Bell, 1901.) 15 from Endymion Series.

Grimm's Fairy Tales. Edited by Marian Edwardes. (Dent, 1901.) 102.

W. E. F. BrtTten.

Undins. Translated from the German of Baron de la Motte Fouqué by Edmund Goace. $4^{\circ}$. (Lawrence and Bullen, 1896.) Io illust.

The Early Pems of Alfred Lord Tennyson. Edited by John Churton-Collins. 8०. (Methuen, 190r.) 10.

Percy Bulcock.

Tbe Blessed Damozel. Dante Gabriel Rossetti. 8०. (Lane, 1900. 'Flowers of Parnassus.') 8 illust.

A Dream of Fair Womsn. Nfred Tennyson. $8^{\circ}$. (Lane, 1902. (' $\mathrm{F}$. of P.') 9.

Herbert Cole.

Gulliver's Trovols. $8^{\circ}$. (Lane, 1900) Profusely illustrated.

The Rubaiyat. 8०. (Lane, Igor. 'Flowers of Parnasuss') 9 illust.

The Nut-Brrown Meid. A new vervion by F. B. MoneyCoutts. 8०. (Lane, 1901. ' F. of P.') 9.

$A$ Ballade upon a Wedding. Sir John Suckling. 8०. (Lane, 1901. ' $F$. of P.') 9.

The Rime of the Ancient Mariner. S. T. Coleridge. 8॰. (Gay and Bird, 1900.) 6.

Phillp Connard.

The Status and the Bust. Robert Browning. 80. (Lane, 1900. 'Flowers of Parnassus.') 9 illust.

Marpessa. Stephen Phillips. 8०. (Lane, 1900. 'F. of P.) 7. 


\section{ENGLISH BOOK-ILLUSTRATION}

Whlter Crane.

The New Forest. J. R. Wise. $4^{\circ}$. (Smith, Elder, 1863.) 63 illust. engraved by W. J. Linton. (A new edition, published by Henry Sotheran, $188_{3}$, with the original illust. and 12 etchings by Heywood Sumner.)

Stories from Memel. Mrs. De Haviland. 12*. (William Hunt, 1864.) 6.

Walter Crane's Toy-Books. Issued in single numbers, from 1865 1876.

Collecied Editions, all published in $4^{\circ}$, by George Routledge, and printed throughout in colours.

Waltor Crane's Picture Book. (1874) 64 pp.

The Marquis of Carabas' Piature Book. (1874.) 64 pp.

Tbe Blue Beard Picture Book. (1876.) 32 pp.

Song of Sixpence Toy-Bwk. (1876.) $32 \mathrm{pp}$.

Cbattering Zack's Picture Book. (1876.) 32 pp.

Tbe Tbrce Bears Piature Baok. (1876.) 32 pp.

Aladdin's Picture Book. (1876.) 24 PP.

The Magic of Kindness. H. and A. Mayhew. 8०. (Cassell, Petter and Galpin, 1869.) 8.

Sunny Days, or a Montb at the Great Stowe. Author of 'Our White Violet.' $8^{\circ}$. (Griffith and Farran, 1871.) 4 in colours.

Our Old Uncle's Home. 'Mother Carey.' 8'. (Griffith and Farran, 1871.) 4 .

The Head of tbe Family. Mrs. Craik. 8. (Macmillan, 1875.) 6. Agatba's Husband. Mrs. Craik. 80. (Macmillan, 1875.) 6. The Quiver of Loos. A Collection of Valentines, Ancient and Modern. $4^{\circ}$. (Marcus Ward, 1876. .) Illust. in colour by Walter Crane and Kate Greenaway.

Carrots. Mrs. Molesworth. 8०. (Macmillan, 1876.) 7.

Songs of Many Seasons. Jemmett Browne. 4․ (Simpkin, Marshall, Pewtress, 1876.) Illust. by $\mathrm{Du}$ Maurier, Walter Crane, C. W. Morgan. I by Walter Crane.

Tbe Baby's Opera. 4\%. (Routledge, 1877.) I1, and illustrative decorations on every page. In colours.

Tbe Cuckw Clock. Mrs. Molesworth. 8०. (Macmillan, 1877.) 7. Grendreotber Dear. Mrs. Molesworth. 80. (Macmillan, 1878.) 7 . The Tapestry Rum. Mrs. Molesworth. 8`. (Macmillan, 1879.) 7 .

Tbe Baby's Bouguet. 4․ (Routledge 1879 .) II, and illustrative decorations on every page. In colours. 
A Cbristmas Cbild. Mrs. Molesworth. 8०. (Macmillan, 1880.) 7 .

The Necklace of Princess Fiorimonde. Mrs. De Morgan. $8^{\circ}$. (Macmillan, 1880 ) 8, and devices.

Herr Baby. Mrs. Molesworth. 80. (Macmillan, 188I.) 7. Also a $4^{\circ}$ edition with 12.

The First of May. A Fairy Masque. Walter Crane. Fol. (Henry Sotheran, 1881.) 52 designs. Text in artist's manuscript.

Household Stories. Translated from the German of the Brothers Grimm by Lucy Crane. 8०. (Macmillan, 1882.) I I, and illustrative head and tailpieces and initials to each story.

Rosy. Mrs. Molesworth. 8०. (Macmillan, 1882.) 7 .

Christmas Tree Land. Mrs. Molesworth. 8०. (Macmillan, 1884.) 7 .

Walter Crane's New Series of Pidture Books. $4^{\circ}$. (Marcus Ward, 1885-6.)

Slate and Pencituania.-Little 2uecn Anne.-Potbooks and Perseverance. 24 pages each, printed in colours.

The Golden Primer. J. M. D. Meiklejohn. . 80. (Blackwood, 1885.) Part I. and Part II. I4 decorative pages in colours in each part.

Folk and Fairy Tales. C. C. Harrison. $8^{\circ}$. (Ward and Downey, 1885.) 24

"Us." Mrs. Molesworth. 8०. (Macmillan, 1885.) 7.

The Sirens Three. Walter Crane. $4^{\circ}$. (Macmillan, 1886.) 41 pages of pictures, with text in artist's manuscript.

The Baby's Own Esop. $4^{\circ}$. (Routledge, 1886.) 56 pages of pietures and text in artist's manuscript. In colours.

Echoes of Hellos. The Tale of Troy and the Story of Orestes from Homer and Aeschylus. With introductory essay and sonnets by Prof. George C. Warr. Fol. (Marcus Ward, 1887.) 82 illustrative decorations.

Four Winds Form. Mrs. Molesworth. 8०. (Macmillan, 1887.) 7 .

Legonds for Lionsl. $4^{\circ}$. (Cassell, 1887.) 40 pages of pietures, text in artist's manuscript. In colours.

A Cbristmes Pesy. Mrs. Molesworth. 80. (Macmillan, 1888.) 7 .

The Happy Prince, and osber tales. Oscar Wilde. $4^{\circ}$. (Nuth, 1888.) Illustrated by Walter Crane and Jacomb Hood. 3 by Walter Crane. 


\section{ENGLISH BOOK-ILLUSTRATION}

The Beok of Wadding Doys. Quotations for every day in the year, compiled by K. E. J. Reid, etc. $4^{\circ}$. (Longmans, 1889.) The Retion Childrem. Mrs. Molesworth. 8॰. Macmillan, 1889.) 7.

Flord's Frast. A Masque of Flowers. Walter Crane. $4^{\circ}$. (Cassell, 1889.) 40 pages of pictures, with text in artist's manuscript. In colours.

The Turtle Doos's Nest. 8०. (Routledge, 1890) 87 illust. by Walter Crane, W. McConnell, Harrison Weir and other artists.

Remascence. A Book of Verse. Walter Crane. Including 'The Sirens Three' and 'Flora's Feast.' $4^{\circ}$. (Elkin Mathews, 1891.) 39 designs, some engraved on wood by Arthur Leverett.

1 Wonder Boak for Girls and Boys. Nathaniel Hawthorne. (Orgood, McIlvaine, 1892.) 60 designs in colours.

The Tempest. 8 illust. to Shakeapeare's 'Tempest.' Engraved and printed by Duncan C. Dallas. (Dent, 1893.)

Two Gentlemen of Veroma. 8 illust. to Shakespeare's 'Two Gentlemen of Verona.' Engraved and printed by Duncan C. Dalles. (Dent, 1894.)

The Sten of the Glittering Plain. Willizm Morris. $4^{\circ}$. (Kelmscott Press. 1894.) 23 illust. by Walter Crane. Borders, titles and initials by William Morris.

The History of Reynard the Far. English Verse by F. S. Ellis. $4^{\circ}$. (David Nuth 1894) Frontispiece and devices. Abo an edition in $1897.8^{\circ}$.

Merry Wroes of Windsor. 8 illust. to Shakespeare's 'Merry Wives of Windsor.' Engraved and printed by Duncan C. Dalks. $4^{\circ}$. (George Allen, 1894)

The Vision of Dante. Miss Harrison. 8०. 1894. 4.

The Faeris Qmesue. In 3 volumes. Edited by Thomss J. Wise. $4^{\circ}$. (George Allen, 1895.) 99 , and headings and tailpieces to each Canto.

Quen Swomarr, or the Tourney of the Lily and the Rose. Walter Crane. 4\%. (Cassell, 1896.) 40 pages of pictures with text in artist's manuscript. In colours.

The Shepheard's Caleadar. Edmund Spenser. $4^{\circ}$. (Harper and Bros., 1898.) 12 and other devices.

Triplets, comprising 'The Baby's Operz' 'The Baby's Bouquet,' and 'The Baby's Own Esop.' Walter Crane. (Routledge, 1899.) Printed by Edmund Evans. $4^{\circ}$. 
A Floral Fantasy, in an Old Englisb Garden. Walter Crane. 8. . (Harper, 1899.) 40 pages of pictures with text in artist's manuscript.

H. Granville Fell.

Our Lad's's Tumbler. A Twelfth Century legend transcribed for Lady Day, 1894. 4\%. (Dent, 1894) 4 illust.

Wagner's Herress. Constance Maud. $8^{\circ}$. (Arnold, 1895.) 8. Ali Babs and the Forty Tbirooss. 32. (Dent, 1895. Banbury Cross Series.) 36.

The Fairy Gifts and Toun Hickatbrift. 32:. (Dent, 1895. Banbury Cross Series.) 36.

Tbe Brok of Fob. $4^{\circ}$. (Dent, 1896.) 22.

$T$ be Song of Solvmon. $4^{\circ}$. (Chapman and Hall, 1897.) 12, and decorations.

Wonder Stories from Herodotys. Re-told by C. H. Boden and W. Barrington D'Almeida. 8". (Harper and Brothers, 1900.) 12, and decorations.

A. J. Gascin.

1 Book of Piatured Carols. Deaigned by member of the Birmingham Art School under the direction of A. J. Gaskin. $4^{\circ}$. (George Allem, 1893.) Illust. by C. M. Gere A. J. Gaskin, Henry Payne, Bernard Sleigh, Fred. Mason, and others. Steries and Fairy Tales. Hans Andersen. 80. (George Allen, 1893.) 100.

A Book of Fairy Tales. Re-told by S. Baring Gould. $8^{\circ}$. (Methuen, 1894.) 20.

Gad King Wenceslas. Dr. Neate. $4^{\circ}$. (Cornish Brothern, Birmingham, 1895.) 6.

The Sbopbeard's Calender. 80. (Kelmocott Press, 1896.) 12.

C. M. Gran.

Ressiam Fairy Tales. R. Nisbet Bain. 8\%. (Lawrence and Bullen, 1893.) 6 illwer.

The Imitation of Cbrist. Thoma i Rempis. Introdution by F. W. Farrar. 8\%. (Methuen 1894 ) 5.

$\triangle$ Brok of Piatrod Carols. See A. F. Gastiv.

J. J. Gurnien.

Wadding Bells. A new old Nurvery Rhyme by A. F. S and E. de Prevemore. $4^{\circ}$. (Simpkin, Marnhall, 1895.) 7 illust. The Gerder of Timen. Mrro. Davideon. 80. (Jarrold and Sones, 18g6.) 38.

An Alhem of Drewiags. Fol. (The White Coctuge, Storne, Kent, 1900.) 20 from various magnainea 


\section{ENGLISH BOOK-ILLUSTRATION}

Laurence Housman.

Fump-ta-Glory Fane. George Meredith. $8^{\circ}$. (Swan, Sonnenschein, 1892.) 44 designs and text in artist's manuscript.

Gablin Market. Christina Rossetti. $8^{\circ}$. (Macmillan, 1893.) Title-page, decorations and 12.

Wcird Tales from Northern Seas. From the Danish of Jonas Lie. 8०. (Kegan Paul, 1893.) 12.

The End of Elfin-town. Jane Barlow. 8०. (Macmillan, 1894.) Title-page, decorations and 8.

A Farm in Fainglexd. Laurence Housman. 8०. (Kegan Paul, 1894.) Frontispiece, title-page and 12.

The House of Foy. Laurence Housman. $8^{\circ}$. (Kegan Paul, 1895.) Frontispiece, title-page and 8.

Green Arras. Laurence Housman. 8०. (Lane, 18g6.) Frontispiece, title-page and 4.

All-Fellows. Laurence Housman. $8^{\circ}$. (Kegan Paul, 1896.) 7. The Were-Wolf. Clemence Housman. $8^{\circ}$. (Lane, 1896.) 6. The Sensitive Plant. P. B. Shelley. $4^{\circ}$. (Aldine House, 1898 .) 12 in photogravure.

Ths Field of Clover. Laurence Housman. 8०. (Kegan Paul, 1898.) Frontispiece, title-page and 10, engraved by Clemence Housman.

Of tbe Imitation of Cbrist. Thomas a Kempis. $8^{\circ}$. (Kegan Paul, 1898.) 5.

The Little Land. Laurence Housman. 8०. (Grant Richards, 1899.) 4

A. Garth Jones.

The Miner Poems of Fohn Milton. 80. (Bell, 1898. Endymion Series.) 46 illust., and decorations.

Cenia Levetus.

Verse Fancies. Edward L. Levetus. $8^{\circ}$. (Chapman and Hall, 1898.) 7 illust.

Songs of Inmocence. William Blake. $3^{\circ}$. (Wells, Gardner, and Darton, 1899.) 14.

W. B. Macdougall.

Cbronicles of Strathearn. 8०. (D2vid Philips, 1896.) 15 illust. The Fall of the Nibelungs. In Two Books. Translated by Margaret Armour. 8\%. (Dent, 1897.) 8 in each book.

Themes Sonnets and Samblances. Margaret Armour. 8. (Elkin Mathews, 1897.) 12.

The Back of Ruth. Introduction by Ernest Rhys. $4^{\circ}$. (Dent, 1896.) 8. 
Isabella, or the Pot of Basil. John Keats. $4^{\circ}$. (Kegan Paub 1898.) 8.

The Shadow of Lrve and other Poems. Margaret Armour. 8*. (Duckworth, 1898.) 2.

Fred. Mason.

A Book of Piaured Carols. See A. F. Gaskin.

The Story of Alexander. Robert Steele. $4^{\circ}$. (David Nutt, 1894.) 5 illust. and headings.

Huon of Bordeaux. Robert Steele. 8०. (George Allen, 1895.) 6 , and headings.

Renaud of Montauban. Robert Steele. 8०. (George Allen, I 897.) 9.

T. Sturge Moore.

The Centaur. The Bacebant. Translated from the French of Maurice de Guérin by $T$. Sturge Moore. Vale Press, 1899.) $4^{\circ} .4$ wood engravings.

Some Fruits of Solitude. William Penn. 8॰. (Essex House Press, IgoI.) Wood engraving on title-page.

L. Fairfax Muckley.

Tbe Facrie Queene. Introduction by Prof. Hales. $4^{\circ}$. (Dent, 1897.) 3 vols. Frontispiece, many decorations and 24

Henry Ospovat.

Sbakespeari's Sonnats. $8^{\circ}$. (Lane, 1899.) ro illust.

Pocms. Matthew Arnold. 8०. Edited by A. C. Benson. (Lane, I goo.) 16, and illustrative decorations.

Charles Rickettr.

$A$ House of Pomegranates. Oscar Wilde. $4^{\circ}$ (Osgood, McIlvaine, I891.) I3 illust. by Charles Ricketts, 4 by C. H. Shannon.

Parms, Dramatic and Lyrical. Lord de Tabley. 8०. (Mathews and Lane, 1893.) 5.

Dapbris and Cbloc. Longus. Translated by Geo. Thornley. $4^{\circ}$. (Mathews and Lane, 1893.) 37 woodcuts drawn on the wood by Charles Ricketts from the designs of Charles Ricketts and Charles Shannon. Engraved by both artists.

Ibe Spbinx. Oscar Wilde. $4^{\circ}$. (Printed at the Ballantyne Press, 1894) 9.

Hero and Leander. Christopher Marlowe and George Chapman. 80. (Vale Press, 1894.) 7, designed and engraved on wood by Charles Ricketts and Charles Shannon.

Nympbidie and the Muses Elixium. Michael Drayton. 80. (Vale Press, I8g6.) Frontispiece engraved on wood. 


\section{ENGLISH BOOK-ILLUSTRATION}

Milton's Early Pocms. 8०. (Vale Press, 1896.) Frontispiecc engraved on wood.

The Excellent Narration of the Marrioge of Cupide and Psyches. Translated from the Latin of Lucius Apuleius, by William Adlington. $8^{\circ}$. (Vale Press, 1897.) 6 wood engravings.

The Book of Thel, Songs of Innocence and Songs of Experience. William Blake. $4^{\circ}$. (Vale Press, 1897.) Frontispiece, engraved on wood.

Blake's Pootical Sketches. 4․ (Vale Press, 1899.) Frontispiece engraved on wood.

HENRY RYLAND.

Holy Gladness. Werds by Edward Oxenford and Music by Sir John Stainer. $4^{\circ}$. (Griffith, Farran, 1889.) 8 illust. in colour by Henry Ryland, and illust. by Louis Davis and others.

Reginald Safage.

Der Ring des Nibelungen. Described by R. Farqubarson Sharp. $4^{\circ}$. (Marshall, Russell, 1898.) 5 illust.

Charles Shannon.

See Charles Ricketts.

'House of Pomegranates,' 'Hero and Leander,' 'Daphnis and Chloe.'

Byam Shaw.

Porms by Robert Browning. 8०. (Bell, 1897.) 20 illust.

Tales from Baccaccio. Joseph Jacobs. $4^{\circ}$. (George Allen, 1899.) 20.

The Prediezed Plague, etc. Hippocrates Junior. 80. (Simpkin, Marshall, 1900.) Many illust. (chiefly vignettes) by Byam Shaw and others.

The Cbiswick Sbakespeare. 8 ${ }^{\circ}$. (Bell, 1899, etc.) S, and decorations in each volume.

Bernard Sleich.

The Sea-King's Daugbter, and otber Pocms. Amy Mark. Printed at the Press of the Birmingham Guild of Handicraft. (G. Napier, Birmingham. Tylston and Edwards, and A. P. Marston, London, 1895.) 4 illust. and 35 decorated pages, engraved by the designer and L. A. Talbot.

A Book of Pialured Carols. See A. F. Gaskin.

Heywood Sumner.

The Avon from Naxby to Trwkesbury. Fol. (Seeley, Jackson and Halliday, 1882.) 21 etchings.

Cinderella: A Fairy Opera. John Farmer and Henry Leigh. 
$4^{\circ}$ (Harrow, J. C. Wilbee; Lendon, Novello, Ewer, 1882.) 17 illust.

Sintram and bis Companions. Translated from the German of De la Motte Fouqué. $4^{\circ}$. (Seeley, Jackson and Halliday, 1883.) Frontispiece and 21.

The New Forest. J. R. Wise. See Walter Crane.

Undine. $4^{\circ}$. (Chapman and Hall, I 888.) I6.

The Besom Moker, and other country Folk Songs. Collected by Heywood Sumner. $4^{\circ}$. (Longmans, 1888.) Frontiopiece and 25 decorated pages, with text in artist's manuscript. Facob and the Raven. Frances M. Peard. 8०. (George Allen, I 896.) 15 , and illustrative decorations.

J. R. WEGUELIN.

Lays of Ancient Rome. Lord Macaulay. 8०. (Longmans, I88I.) $4 \mathrm{I}$ illust.

Anacreon: with Thomas Stanley's translation. Edited by A. H. Bullen. $8^{\circ}$. (Lawrence and Bullen, 1892.) II.

The Little Mermaid and otber Stories. Hans Andersen. Translated by R. Nisbet Bain. $4^{\circ}$. (Lawrence and Bullen, 1893.) $6 \mathrm{r}$.

Catullus : witb the Pervigilium Veneris. Edited by S. G. Owen. 8.. (Lawrence and Bullen, I 893.) 8.

The Wooing of Malkatoon. Commodus. Lewis Wallace. $8^{\circ}$. (Harper and Bros., 18g8.) Illustrated by J. R. Weguelin and Du Mond. 6 to Commodus by J. R. Weguelin.

PatTen Wilson.

Miracle Plays. Our Lord's Coming and Childhood. Katherine Tynan Hinkson. $8^{\circ}$. (Lane, 1895.) 6 illust.

$A$ Houseful of Rebels. Walter C. Rhoades. 8०. (Archibald Constable, 1897.) 10.

Selections from Coleridge. Andrew Lang. $8^{\circ}$. (Longmans, 1898.) 18.

King Fobn. Edited by J. W. Young. $8^{\circ}$. (Longmans, 1899 . Swan Shakespeare.) 9.

Paul V. Woodrotre.

Songs from Shakespeeri's Plays. Edited by E. Rhys. $4^{\circ}$. (Aldine House, 1898.) 12 illust.

Tbe Little Flowers of St. Francis of Assisi. $8^{\circ}$. (Kegan Paul, 1899.) 8.

The Confessions of St. Augustine. $8^{\circ}$. (Kegan Paul, 1900.) Title-page by Lawrence Housman, illus. by P. V. Woodroffe. Engraved upon wood by Miss Housman. 